\title{
Physiology of Pseudomonas aeruginosa in biofilms as revealed by transcriptome analysis
}

\author{
James P Folsom 1 , Lee Richards ${ }^{1,2}$, Betsey Pitts ${ }^{1}$, Frank Roe ${ }^{1,3}$, Garth D Ehrlich $^{4}$, Albert Parker ${ }^{1}$, Aurélien Mazurie ${ }^{5}$, \\ Philip S Stewart ${ }^{1 *}$
}

\begin{abstract}
Background: Transcriptome analysis was applied to characterize the physiological activities of Pseudomonas aeruginosa grown for three days in drip-flow biofilm reactors. Conventional applications of transcriptional profiling often compare two paired data sets that differ in a single experimentally controlled variable. In contrast this study obtained the transcriptome of a single biofilm state, ranked transcript signals to make the priorities of the population manifest, and compared ranki ngs for a priori identified physiological marker genes between the biofilm and published data sets.

Results: Biofilms tolerated exposure to antibiotics, harbored steep oxygen concentration gradients, and exhibited stratified and heterogeneous spatial patterns of protein synthetic activity. Transcriptional profiling was performed and the signal intensity of each transcript was ranked to gain insight into the physiological state of the biofilm population. Similar rankings were obtained from data sets published in the GEO database http://www.ncbi.nlm.nih. gov/geo. By comparing the rank of genes selected as markers for particular physiological activities between the biofilm and comparator data sets, it was possible to infer qualitative features of the physiological state of the biofilm bacteria. These biofilms appeared, from their transcriptome, to be glucose nourished, iron replete, oxygen limited, and growing slowly or exhibiting stationary phase character. Genes associated with elaboration of type IV pili were strongly expressed in the biofilm. The biofilm population did not indicate oxidative stress, homoserine lactone mediated quorum sensing, or activation of efflux pumps. Using correlations with transcript ranks, the average specific growth rate of biofilm cells was estimated to be $0.08 \mathrm{~h}^{-1}$.
\end{abstract}

Conclusions: Collectively these data underscore the oxygen-limited, slow-growing nature of the biofilm population and are consistent with antimicrobial tolerance due to low metabolic activity.

\section{Background}

The physiological activities of bacteria growing in biofilms are difficult to divine, because these activities are diverse, change with time as the biofilm develops, and are subject to extreme micro scale spatial heterogeneity [1]. It is also clear that the metabolism and activities of a particular biofilm will be shaped by the specific chemical and physical environment in which it grows. These realities make it difficult to develop a consensus picture of the physiology of the biofilm state as there is so little overlap in the lists of genes differentially

\footnotetext{
* Correspondence: phil_s@biofilm.montana.edu

${ }^{1}$ Center for Biofilm Engineering and Department of Chemical and Biological Engineering, P. O. Box 173980 Montana State University - Bozeman Bozeman, Montana 59717-3980, USA

Full list of author information is available at the end of the article
}

expressed between the planktonic and biofilm states of Pseudomonas aeruginosa prepared by different experimenters [2-7].

However, there are biofilm physiological traits, such as antimicrobial tolerance [8] and reduced growth rate [1], for which there is considerable consensus. These robust phenotypes, with their functional and evolutionary importance, should have discernable biochemical and genetic bases. We sought to understand these phenotypes with an unconventional interpretation of transcriptional profiling studies. Conventional interpretations of transcriptional profiling studies compare two paired data sets that differ in a single controlled variable (e.g., iron concentration, quorum sensing signal molecule addition). In this study, we have obtained the transcriptome for a single biofilm specimen, ranked the
C Biomed Central 
transcripts based on the signal intensity to make the priorities of the population manifest, and compared rankings for a priori identified physiological marker genes between the biofilm and a number of published data sets. For example, if we wish to discern whether the biofilm is responding to iron limitation, we first identify a set of genes that are up-regulated in response to iron deprivation (e.g. the work of Ochsner [9]). The rank of each of these transcripts in the biofilm data set is then compared to transcript ranks for the same genes in data sets collected from both rapidly growing and deliberately iron-starved cultures. In this way it becomes possible to evaluate physiological activities in the biofilm rather than just documenting differences between the biofilm and a reference state.

In the experiments reported here, RNA was extracted from an entire, homogenized biofilm specimen. An obvious concern with this approach is that it neglects the inherent biological heterogeneity of the biofilm [1]. We would like to address this concern upfront with two points. First, just because a population is heterogeneous does not mean that measurements of population averages are invalid. Population averages are very widely and informatively used in biology. Second, we suggest that even the concept of an average may not be appropriate in this case. The current conceptual model of $P$. aeruginosa drip-flow biofilms is that they consist of two distinct populations: an aerobic, metabolically active upper layer and a lower, and larger, layer consisting of inactive cells containing very low levels of mRNA $[10,11]$. Because the inactive cells contain so little RNA, this majority is expected to be essentially invisible on the microarray. From this perspective, the transcriptomes reported here may best be thought of as reflecting the properties of the transcriptionally-active subpopulation rather than the average behavior of the entire population. These concepts are elaborated on in the Results and Discussion.

\section{Results and Discussion}

Three day old drip flow biofilms of $P$. aeruginosa were characterized with respect to antibiotic tolerance, oxygen availability, and microscale patterns of protein synthetic activity. These biofilms contained $9.56 \pm 0.31 \mathrm{cfu} \mathrm{cm}^{-2}$.

\section{Reduced antibiotic susceptibility of biofilm bacteria}

$P$. aeruginosa cells grown in biofilms were protected from killing by tobramycin and ciprofloxacin, in comparison to actively growing planktonic bacteria. Both antibiotics rapidly and effectively reduced viable cell numbers in an aerobic, planktonic culture. After $12 \mathrm{~h}$ of treatment with $10 \mu \mathrm{g} \mathrm{ml}^{-1}$ tobramycin or $1.0 \mu \mathrm{g} \mathrm{ml}^{-1}$ ciprofloxacin, planktonic log reductions measured were $3.18 \pm 1.79(\mathrm{n}=3, \pm \mathrm{SD})$ and $4.84 \pm 0.55(\mathrm{n}=3, \pm \mathrm{SD})$ for tobramycin and ciprofloxacin, respectively. In contrast, neither antibiotic was very effective against biofilms of $P$. aeruginosa. After $12 \mathrm{~h}$ exposure to antibiotic in continuously flowing medium, the log reductions in viable cell numbers were $0.72 \pm 0.56(\mathrm{n}=3, \pm \mathrm{SD})$ and $1.37 \pm$ $0.06(\mathrm{n}=3, \pm \mathrm{SD})$ for tobramycin and ciprofloxacin, respectively. The log reductions measured for biofilm bacteria were $23 \%$ and $28 \%$ of the planktonic log reductions for the two antibiotics, respectively. Reduced killing of the biofilm in comparison to planktonic cells was statistically significant ( $p=0.04$ and $p=0.0004$ for tobramycin and ciprofloxacin, respectively). These data demonstrate that these drip-flow biofilms exhibit the antibiotic-tolerant phenotype that is considered a hallmark of the biofilm mode of growth.

When biofilm bacteria were dispersed prior to antibiotic exposure, they again became susceptible to the antibiotics. Log reductions measured for biofilm cells resuspended into aerated medium and treated with tobramycin or ciprofloxacin for $12 \mathrm{~h}$ were $3.90 \pm 0.10$ and $4.40 \pm 0.53$, respectively. This degree of killing was the same as that measured for planktonic bacteria, indicating that susceptibility was rapidly and fully restored upon dispersal of cells from the biofilm.

\section{Low oxygen concentrations in biofilms}

An oxygen microelectrode was used to demonstrate the presence of oxygen concentration gradients in this system (Figure 1A). The oxygen concentration in the flowing fluid above the biofilm was approximately $6 \mathrm{mg} \mathrm{l}^{-1}$. Oxygen concentration decreased to $0.2 \mathrm{mg} \mathrm{l}^{-1}$ or less inside the biofilm. A similar profile was measured in a duplicate experiment. The oxygen concentrations shown in Figure 1A may not define the lower bound of oxygen concentration inside the biofilm because the electrode was positioned only partway into the biofilm, to avoid electrode breakage.

The utilization of oxygen by bacteria is coupled to their simultaneous uptake and oxidation of a carbon source. To investigate this coupling, the oxygen microelectrode was positioned at a depth part way into the biofilm where the oxygen concentration was less than $0.5 \mathrm{mg} \mathrm{l}^{-1}$ (Figure 1B). The medium flowing over the biofilm was then changed from complete PBM to PBM lacking glucose and ammonium sulfate. Within a few minutes after switching to this starvation medium, the oxygen concentration in the biofilm abruptly rose to approximately $5 \mathrm{mg} \mathrm{l}^{-1}$. When the complete medium containing glucose and the nitrogen source was restored, the oxygen concentration quickly dropped back to its previous low level. Upon switching once again to the starvation medium, the oxygen concentration again returned to the higher level. Restoring the complete medium again caused the oxygen concentration 

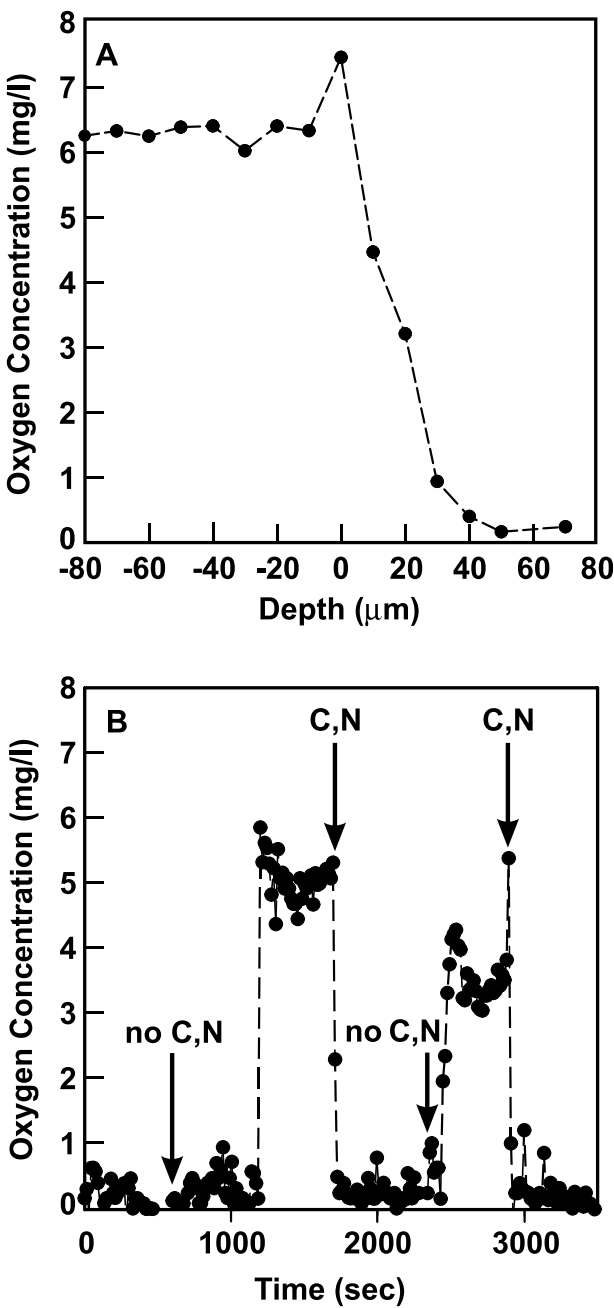

Figure 1 Oxygen concentrations in Pseudomonas aeruginosa biofilms. Panel A shows a representative oxygen concentration profile with depth in the biofilm. Zero on the $x$-axis corresponds to the biofilm-bulk fluid interface. Negative positions are located in the fluid film above the biofilm and positive positions are located inside the biomass. Panel B shows the coupling between oxygen and glucose utilization. The oxygen microelectrode was positioned at a location within the biofilm where the oxygen concentration was low. The medium flowing over the biofilm was switched between one containing glucose and ammonium ion ( $\mathrm{C}, \mathrm{N})$ and a medium lacking these constituents (no $C, N$ ) as indicated by the arrows. The complete medium is present at time zero.

to fall. The same behavior was observed in a duplicate experiment. These experiments show that oxygen and glucose utilization are interdependent.

\section{Heterogeneous patterns of protein synthetic activity in biofilms}

The induction of a GFP has been used to reveal regions of active protein synthesis in biofilms [12-14]. When this technique was applied to $P$. aeruginosa biofilms grown in drip-flow reactors, a stratified pattern of

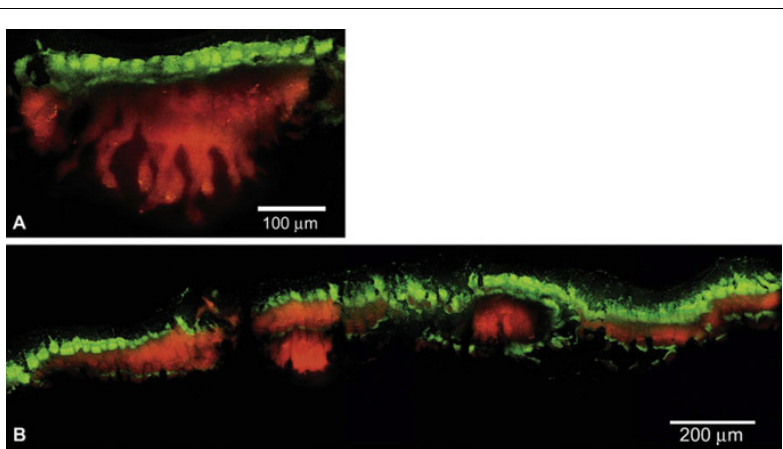

Figure 2 Spatial pattern of protein synthetic activity, as revealed by transient expression of an inducible GFP (green) in a $P$. aeruginosa biofilm grown in a drip-flow reactor. In this frozen section, the steel substratum was formerly at the bottom and the aerated nutrient medium at the top. Rhodamine B counterstaining (red) indicates the extent of the biofilm.

activity was observed (Figure 2). Expression of GFP was localized in a band at the top of the biofilm adjacent to the source of nutrients and oxygen. The dimension of the GFP-expressing zone averaged $66 \pm 30 \mu \mathrm{m}(\mathrm{n}=3$, \pm $\mathrm{SD})$. The average thickness of the entire biofilm was 170 $\pm 78 \mu \mathrm{m}(\mathrm{n}=3, \pm \mathrm{SD})$ (Table 1$)$. While the predominant zone of activity was along the air interface (Figure 2A), GFP fluorescence was occasionally observed in thin strata in the interior and even at the bottom of the biofilm (Figure 2B). The observation of fluorescent GFP at the bottom of the biofilm argues against the interpretation that these patterns are an artifact of incomplete IPTG penetration. In prior studies, the facile penetration of IPTG throughout $P$. aeruginosa biofilms has been demonstrated $[12,14]$.

\section{Transcriptional profiling of biofilms - nutritional and growth status}

The RNA was extracted from 3-day old $P$. aeruginosa drip-flow reactor grown biofilms and subjected to global transcriptional profiling. These microarray data have been deposited to Gene Expression Omnibus (GEO) accession GSE22164. We compared the expression of individual genes or groups of genes indicative of specific physiological activities by analyzing the rank of the selected transcript in the drip flow biofilm transcriptome across 6 different experiments and planktonic comparator transcriptomes [15-22] listed in Table 2 and Additional file 1.

When grown on glucose, $P$. aeruginosa expresses an outer membrane protein, OprB, which is involved in the uptake of sugars [23]. Figure 3A compares the rank of the oprB (PA3186) transcript in several data sets, including our drip-flow reactor biofilm. This gene is highly expressed in the biofilm ( $n=6$, average rank of 26) and also highly expressed in one other transcriptome from a 
Table 1 Determination of mean biofilm thickness and mean dimension of the zone in which GFP was expressed.

\begin{tabular}{lllll}
\hline Strain (plasmid) & IPTG $(\mathbf{m M})$ & $\begin{array}{l}\text { Biofilm*+ Thickness } \\
(\boldsymbol{\mu m} \pm \mathbf{S D})\end{array}$ & $\begin{array}{l}\text { GFP zone } \\
(\boldsymbol{\mu m} \pm \mathbf{~ S D})\end{array}$ & $\begin{array}{l}\text { Maximumt dimension } \\
\text { (arbitrary } \pm \text { SD) }\end{array}$ \\
\hline PAO1 (pAB1) & 0 & $165 \pm 100$ & none & $24 \pm 26$ \\
PAO1 (pAB1) & 1 & $170 \pm 78$ & $66 \pm 30$ & $166 \pm 61$ \\
PAO1 (pMF54) & 1 & $120 \pm 38$ & none & $3 \pm 1$
\end{tabular}

*The thickness of the area of GFP expression as well as the overall thickness of the biofilm was measured 3 times. Measurement of Pseudomonas aeruginosa PAO1 carrying plasmid pAB1 containing an IPTG-inducible GFP with and without IPTG are compared with $P$. aeruginosa carrying plasmid pMF54 lacking GFP.

†The uncertainties indicated are standard deviations.

study [22] in which the bacteria were grown on a glucose-minimal medium (average of rank 7). The rank of the PA3186 transcript is lower in cells grown on minimal media supplemented with acetate or citrate, lower still on complex media such as LB or BHI, and lowest of all on a minimal amino acid medium. The straightforward interpretation of this comparison is that the strong expression of oprB in the drip-flow biofilm implies the presence of glucose in the system. Since the medium used in this study contained glucose as the sole carbon and energy source, these results illustrate the face validity of our approach.

To further demonstrate the potential to diagnose metabolic activities from transcript ranks, we conducted a more comprehensive analysis of relationship between the presence or absence of glucose and the ranks of selected gene transcripts. Fifty eight samples were identified in which no glucose was present in the medium. Eleven samples were identified in which glucose was the sole or predominant carbon source. Differences in the ranks of pairs of genes, identified by inspection, were found to discriminate the glucose-present and glucoseabsent data sets (Figure 4A). The drip-flow biofilm data group with the glucose-present comparators, as expected. The six glucose-absent points that overlap with the glucose-present cluster are from a single investigation in which glycerol was the predominant carbon source. The extensive commonality of pathways for catabolism of glucose and glycerol may explain this overlap.

Alvarez-Ortega and Harwood [15] identified genes induced under conditions of low oxygen concentration. From their results, we identified a subset of seven genes that were particularly strongly induced by low oxygen and whose transcript rank increased monotonically with decreasing oxygen concentration. Figure 3B compares the rank for these seven genes between drip-flow biofilms in this study and the Alvarez-Ortega and Harwood [15] data. The rankings of the transcripts for the biofilm were consistent with low oxygen concentrations for six

Table $2 P$. aeruginosa transcriptional profiling data sets used for comparison.

\begin{tabular}{|c|c|c|c|c|}
\hline GEO ID & Symbol Color & Medium & n & Reference \\
\hline GSE6741 & $\begin{array}{l}\text { - } 20 \% \mathrm{O}_{2} \text { - light green } \\
\text { - } 2 \% \mathrm{O}_{2} \text { - gold } \\
\text { - } 0.4 \% \mathrm{O}_{2} \text { - red } \\
\text { - } 0 \% \mathrm{O}_{2}+\text { nitrate - dark green }\end{array}$ & minimal amino acids $37^{\circ} \mathrm{C}$, sparged and stirred exponential phase, $\mathrm{OD} \sim 0.08$ & 2 & [15] \\
\hline GSE2430 & - untreated control - pink & $\mathrm{BHI}, 37^{\circ} \mathrm{C}$, shaken; early stationary phase, $\mathrm{OD} \sim 2.8$ & 2 & [18] \\
\hline GSE4152 & $\begin{array}{l}\text { - untreated control - yellow } \\
\text { - Cu stressed - blue }\end{array}$ & MOPS buffered $L B, 37^{\circ} \mathrm{C}$, early exponential phase, $\mathrm{OD} \sim 0.2$ & 2 & [20] \\
\hline GSE2885 & $\begin{array}{l}\bullet \mathrm{OD} \sim 0.2 \text { - light gray } \\
\bullet \mathrm{OD} \sim 1.3 \text { - white } \\
\bullet \mathrm{OD} \sim 2.1 \text { (Fe limited) - purple }\end{array}$ & minimal glucose, $37^{\circ} \mathrm{C}$, sparged and stirred, three points in batch culture & 2 & [22] \\
\hline GSE5604 & - untreated control - light blue & minimal acetate, $20^{\circ} \mathrm{C}$, chemostat with dilution rate $0.06 \mathrm{~h}^{-1}$ & 2 & [17] \\
\hline GSE7704 & - control - brown & minimal citrate, $37^{\circ} \mathrm{C}$, shaken, $\mathrm{OD} \sim 0.6$ & 3 & [19] \\
\hline GSE5443 & - control - dark blue & $\mathrm{LB}, 37^{\circ} \mathrm{C}$ & 2 & [16] \\
\hline GSE8408 & - control - dark gray & minimal succinate and non-sulfur containing amino acids, $30^{\circ} \mathrm{C}$, shaken, $\mathrm{OD} \sim 0.2$ & 3 & [21] \\
\hline
\end{tabular}



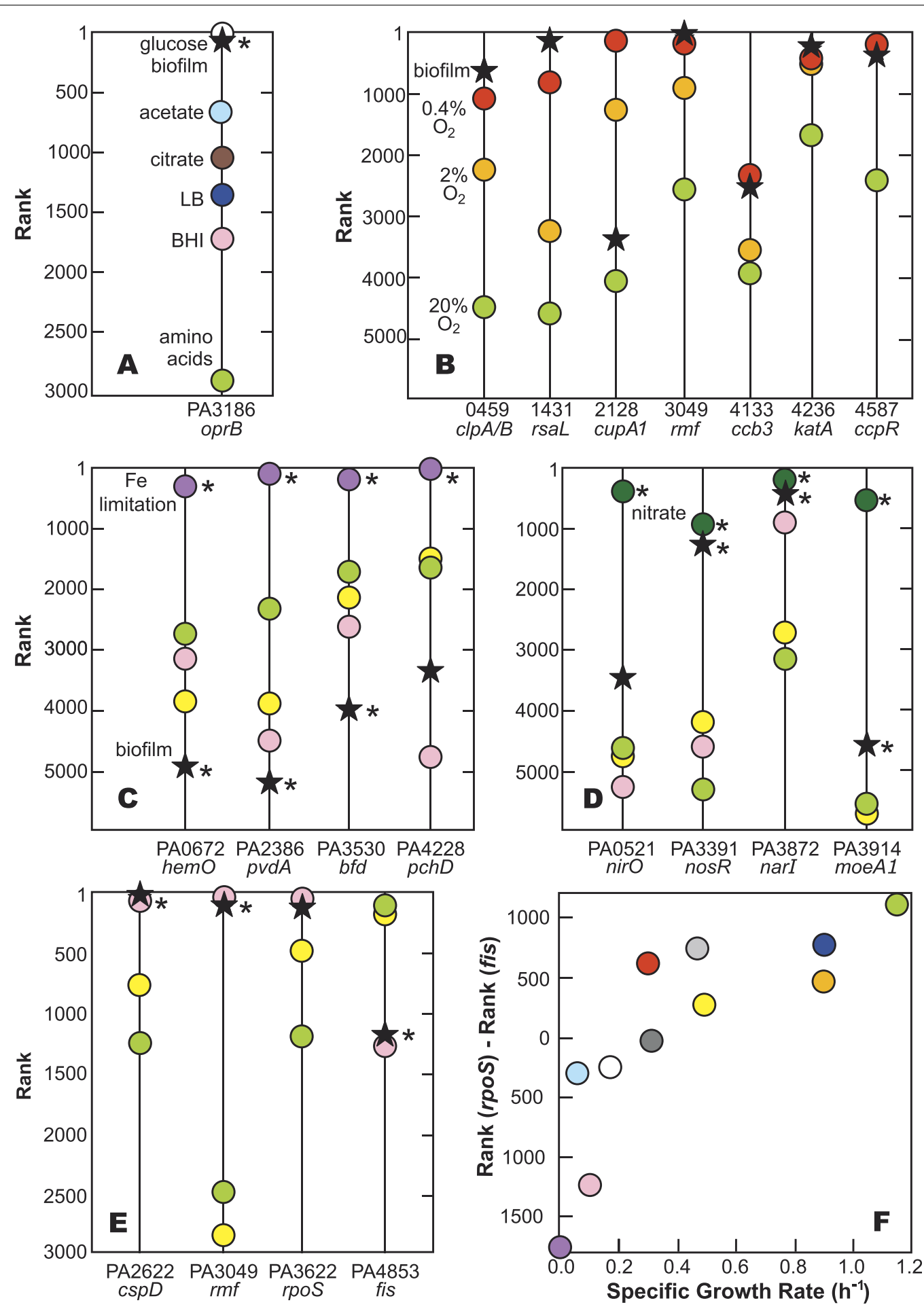

Figure 3 Comparison of transcript ranks for genes related to nutritional status and growth state. Shown are comparisons for selected genes involved in glucose uptake (A); oxygen limitation (B); iron limitation (C); presence of nitrate (D); and growth phase (E). Panel $F$ shows the association between the difference in gene ranks for PA3622 (rpoS) and PA4853 (fis) and specific growth rate. Colored symbols correspond to individual data sets as given in Table 2 and Additional file 1. An asterisk next to a data point indicates a statistically significant difference between the indicated data set and the combined data of three standard comparator data sets (see Materials and Methods for specifics). In panel $\mathrm{E}$, which concerns growth rate, the statistical comparison is to the two comparator data sets in exponential phase; the untreated control of Nalca et al was omitted. Where a label such as "Fe limitation" appears, it denotes a transcriptome that can be considered a positive control. Where no such label appears, a suitable positive control data set was lacking. 

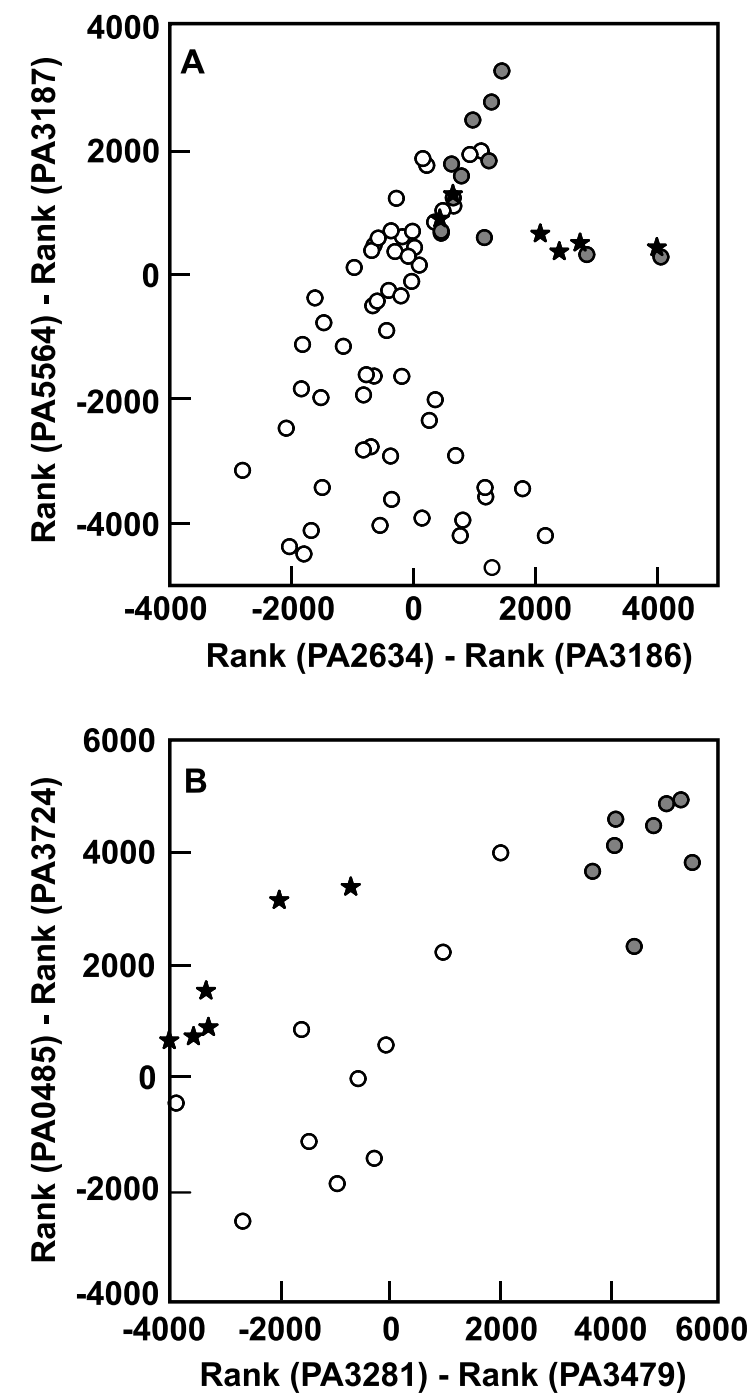

Figure 4 Discrimination of glucose metabolism (A) and homoserine lactone quorum sensing (B) based on differences in transcript ranks. Open symbols are glucose-absent or quorum sensing negative comparators in panels $A$ and $B$, respectively. Filled symbols are glucose-present and quorum sensing positive comparators in panels A and B, respectively. Stars indicate drip-flow biofilm samples. The genes appearing in these graphs are annotated as: PA5564, gidB, glucose inhibited division protein B; PA3187, probable ATP-binding component of ABC transporter; PA2634, aceA, isocitrate lyase; PA3186, glucose/carbohydrate outer membrane porin OprB precursor; PA0485, conserved hypothetical protein; PA3724, lasB, elastase; PA3281, hypothetical protein; rh/A, rhamnosyltransferase chain $A$.

of seven transcripts. This comparison indicates that the biofilm experienced oxygen limitation.

A recent investigation reported 117 genes induced by transferring $P$. aeruginosa from aerobic to anaerobic conditions [24]. Thirty-five genes appearing on this list also appear in Table 3, a significant overlap $\left(p=3 \times 10^{-12}\right.$; random chance would predict an overlap of approximately
2 genes). This overlap reinforces the interpretation of an oxygen-limited physiology of the drip-flow biofilm population.

We identified four genes strongly up-regulated by iron limitation [9] and compared their expression between drip-flow biofilm, three standard comparison data sets $[15,18,20]$, and a positive control in which the bacterial culture was deliberately iron-limited (Figure 3C) [22]. All four genes were highly ranked in the iron-limited positive control. The expression rank of these four genes in the drip flow biofilm was consistently lower in comparison to the reference data sets. These data suggest that bacteria in the drip-flow biofilm as grown in this study did not experience limitation for iron. The concentration of iron in the medium, added in the form of ferrous ammonium sulfate, was $1.5 \mu \mathrm{M}$.

From the literature, we identified four genes that are induced by the presence of nitrate in the medium, either under aerobic or anaerobic conditions [25]. The expression rank of these genes is compared in Figure 3D. The rank for the drip-flow biofilm for all four genes was higher than the three standard comparison data sets and lower than a nitrate-amended positive control. The medium used to grow the biofilm did not contain added nitrate.

Figure 3E presents a comparison of gene rank for four growth phase responsive genes. Three genes associated with stationary phase, $c s p D$, rmf, and rpoS, [26-29] were very highly ranked in both our drip flow biofilm and the comparison data set that was sampled in stationary phase. The fourth gene whose expression is associated with early exponential phase growth, fis, [26,29] showed the inverse ranking. The biofilm and stationary phase culture had similar ranks for the fis gene, while the two systems in which bacteria were rapidly growing had much higher ranks. These comparisons suggest that many of the cells in the biofilm exhibit stationary phase character.

To further explore the potential relationship between transcript levels for these genes and growth state, we plotted gene rank for fis and rpoS as a function of specific growth rate, where a growth rate was reported or optical density versus time data permitted a quantitative estimation (not shown). Though the data is somewhat noisy, it is clear that rpoS gene rank decreases with increasing growth rate. The rank of the fis gene is relatively constant above a specific growth rate of approximately $0.2 \mathrm{~h}^{-1}$, and decreases below this growth rate. The difference in gene rank between rpoS and fis increases with specific growth rate (Figure 3F). This analysis points to the possibility of inferring growth rate from transcriptomic data. For example, in the drip-flow biofilm the difference in rpoS and fis gene rank was $-1135 \pm 296(\mathrm{n}=6, \pm \mathrm{SD})$. From Figure 3F, this 
Table 3 Genes expressed more highly in untreated $P$. aeruginosa drip-flow reactor biofilms $(n=6)$ than in several comparator transcriptomes.

\begin{tabular}{|c|c|c|c|c|c|}
\hline & & DFB* & Comp.* & & \\
\hline Gene ID & Name & Rank & Rank & Note & Description \\
\hline PA0038 & & 185 & 1734 & & hypothetical protein \\
\hline PA0105-0107 & $\operatorname{COXBA}$ & 174 & 3225 & $\mathrm{O}_{2}$ & cytochrome c oxidase \\
\hline PA0200 & & 145 & 3494 & & hypothetical protein \\
\hline PA0284 & & 77 & 712 & & hypothetical protein \\
\hline PA0409 & pilH & 56 & 539 & & Type IV pili biogenesis \\
\hline PA0515-0519 & nirFCMS & 207 & 2547 & $\mathrm{O}_{2}$ & nitrite reduction \\
\hline PA0523-0524 & norCB & 177 & 3770 & $\mathrm{O}_{2}$ & nitric oxide reductase \\
\hline PA0586-0588 & & 123 & 1848 & $\mathrm{O}_{2}$ & conserved hypothetical and serine protein kinase \\
\hline PA0713 & & 103 & 3107 & $\mathrm{O}_{2}$ & conserved hypothetical protein \\
\hline PA717-0726 & & 185 & 3323 & & hypothetical proteins of bacteriophage Pf1 \\
\hline PA0763 & mucA & 30 & 296 & & anti-sigma factor \\
\hline PA1041 & & 47 & 1850 & & probable outer membrane protein precursor \\
\hline PA1174 & napA & 270 & 2433 & $\mathrm{O}_{2}$ & periplasmic nitrate reductase \\
\hline PA1178 & oprH & 5 & 831 & & outer membrane protein $\mathrm{H} 1$ precursor \\
\hline PA1190 & & 105 & 3558 & & conserved hypothetical protein \\
\hline PA1414 & & 14 & 756 & & hypothetical protein \\
\hline PA1431 & rsal & 45 & 1835 & $\mathrm{O}_{2}$ & regulatory protein \\
\hline PA1555-1556 & & 64 & 1312 & $\mathrm{O}_{2}$ & cytochrome c oxidase \\
\hline PA1592 & & 4 & 67 & & hypothetical protein \\
\hline PA1673 & & 152 & 2346 & $\mathrm{O}_{2}$ & hypothetical protein \\
\hline PA1746 & & 173 & 2016 & $\mathrm{O}_{2}$ & hypothetical protein \\
\hline PA1982-1983 & $\operatorname{exa} A B$ & 315 & 5317 & & alcohol dehydrogenase, cytochrome c550 \\
\hline PA2274 & & 378 & 3473 & & putative monooxygenase \\
\hline PA2381 & & 64 & 1279 & $\mathrm{O}_{2}$ & conserved hypothetical protein \\
\hline PA2485 & & 161 & 2704 & & hypothetical protein \\
\hline PA2501 & & 133 & 1858 & & hypothetical protein \\
\hline PA2622 & $\operatorname{csp} D$ & 19 & 591 & & stationary phase replication inhibitor \\
\hline PA2754 & & 140 & 1797 & & conserved hypothetical protein \\
\hline PA2780-2781 & & 205 & 2983 & & hypothetical proteins \\
\hline PA2807-2808 & ptrA & 47 & 3378 & $\mathrm{Cu}$ & hypothetical and two-component repressor \\
\hline PA2862 & $\operatorname{lip} A$ & 176 & 2785 & & lactonizing lipase precursor \\
\hline PA2883 & & 121 & 2207 & & hypothetical protein \\
\hline PA2937 & & 53 & 3144 & & hypothetical protein \\
\hline PA3040 & & 40 & 553 & & conserved hypothetical protein \\
\hline PA3049 & $r m f$ & 11 & 1575 & $\mathrm{O}_{2}$ & ribosome modulation factor \\
\hline PA3126 & $i b p A$ & 134 & 1382 & & heat-shock protein IbpA \\
\hline PA3181 & & 226 & 2020 & & 2-keto-3-deoxy-6-phosphogluconate aldolase \\
\hline PA3186-3190 & $o p r B$ & 68 & 1936 & & glucose uptake \\
\hline PA3205 & & 16 & 1033 & & hypothetical protein \\
\hline PA3235 & & 101 & 2118 & & conserved hypothetical protein \\
\hline PA3309 & & 33 & 1076 & $\mathrm{O}_{2}$ & universal stress protein \\
\hline PA3369-3371 & & 196 & 3302 & & hypothetical proteins \\
\hline PA3412 & & 163 & 3772 & $\mathrm{Cu}$ & probable transcriptional regulator \\
\hline PA3415 & & 225 & 2682 & & probable dihydrolipoamide acetyltransferase \\
\hline PA3416-3417 & & 259 & 2723 & & pyruvate dehydrogenase \\
\hline PA3418 & ldh & 52 & 2352 & & leucine dehydrogenase \\
\hline PA3515-3519 & & 92 & 2804 & $\mathrm{Cu}$ & hypothetical proteins and probable lyases \\
\hline PA3523 & & 128 & 3765 & $\mathrm{Cu}$ & probable RND efflux membrane fusion protein \\
\hline
\end{tabular}


Table 3 Genes expressed more highly in untreated $P$. aeruginosa drip-flow reactor biofilms $(n=6)$ than in several comparator transcriptomes. (Continued)

\begin{tabular}{|c|c|c|c|c|c|}
\hline PA3552 & $\mathrm{pmrH}$ & 269 & 2400 & & lipopolysaccharide modification \\
\hline PA3572 & & 107 & 1616 & & hypothetical protein \\
\hline PA3577 & & 253 & 3216 & & hypothetical protein \\
\hline PA3690-3691 & & 57 & 1482 & $\mathrm{Cu}$ & probable metal-transporting P-type ATPase \\
\hline PA3792 & leuA & 38 & 603 & & 2-isopropylmalate synthase \\
\hline PA3819 & & 44 & 508 & & conserved hypothetical protein \\
\hline PA3920 & & 79 & 2577 & $\mathrm{Cu}$ & probable metal transporting P-type ATPase \\
\hline PA3973 & & 292 & 2829 & & probable transcriptional regulator \\
\hline PA4352 & & 114 & 1316 & $\mathrm{O}_{2}$ & conserved hypothetical protein \\
\hline PA4550-4551 & fimUpilV & 167 & 2088 & & type 4 fimbrial biogenesis proteins \\
\hline PA4577 & & 124 & 2292 & & hypothetical protein \\
\hline PA4607-4611 & & 136 & 2173 & & hypothetical proteins \\
\hline PA4739 & & 143 & 1345 & $\mathrm{O}_{2}$ & conserved hypothetical protein \\
\hline PA4773,4776 & $p m r B$ & 166 & 2538 & & hypothetical and two-component sensor \\
\hline PA4781-82 & & 202 & 2538 & & probable two-component response regulator \\
\hline PA5100 & hutU & 258 & 2660 & $\mathrm{O}_{2}$ & urocanase \\
\hline PA5212 & & 29 & 881 & & hypothetical protein \\
\hline PA5427 & $\operatorname{adh} A$ & 112 & 2664 & $\mathrm{O}_{2}$ & alcohol dehydrogenase \\
\hline PA5446 & & 7 & 866 & & hypothetical protein \\
\hline PA5460 & & 118 & 3962 & & hypothetical protein \\
\hline PA5475 & & 294 & 2787 & $\mathrm{O}_{2}$ & hypothetical protein \\
\hline
\end{tabular}

*Average Rank in drip flow biofilms (DFB) and three comparator microarray data sets (Comp. Rank) named in the Materials and Methods.

difference corresponds to a specific growth rate of approximately $0.08 \mathrm{~h}^{-1}$. Taking the results of Figures $3 \mathrm{E}$ and $3 \mathrm{~F}$ together, it appears as if bacteria in the biofilm were growing very slowly.

\section{Oxygen availability limits growth in biofilm}

In this experimental system, two potentially limiting substrates for bacterial growth were glucose and oxygen. The composition of the medium used ensured excess nitrogen, phosphorous, sulfur, and other elemental requirements. For example, the molar ratio of ammonium to glucose carbon was 2.3 , which provided approximately ten-fold excess nitrogen.

There is no basis for anticipating that glucose was limiting in any part of the biofilms that were grown in this study. This can best be appreciated by a simple calculation. As derived by Williamson and McCarty [30], the metabolic substrate that will first be depleted in a biofilm can be determined by calculating the dimensionless quantity $D_{\mathrm{eG}} S_{\mathrm{G}} / D_{\mathrm{eO} 2} S_{\mathrm{O} 2} Y_{\mathrm{GO} 2}$. This ratio is a measure of the relative diffusive fluxes of glucose and oxygen into the biofilm, where $D_{\mathrm{e}}$ denotes the effective diffusion coefficient of the respective substrate in the biofilm, $S$ denotes the bulk fluid concentration of the respective substrate, and $Y_{\mathrm{GO} 2}$ is the stoichiometric coefficient relating the consumption of glucose and oxygen. In the present case, we take the effective diffusion coefficients of oxygen and glucose to be
$1.53 \times 10^{-5} \mathrm{~cm}^{2} \mathrm{~s}^{-1}$ and $2.69 \times 10^{-6} \mathrm{~cm}^{2} \mathrm{~s}^{-1}$, respectively [31]. The yield coefficient has been carefully measured, in biofilms of this bacterium, and is $2.25 \mathrm{~g}$ glucose per g oxygen [32]. With the bulk fluid concentration of glucose at $200 \mathrm{mg} \mathrm{l}^{-1}$ and the bulk fluid concentration of oxygen at $6 \mathrm{mg} \mathrm{l}^{-1}$, the quantity given by the ratio above has a value of 2.6 . This value being greater than 1 means that glucose is provided in excess and that oxygen is the limiting substrate. This interpretation is consistent with the strong expression of oprB in biofilm specimens (Figure 3A) and the analysis shown in Figure 4A.

Microelectrode measurements provided direct chemical evidence of reduced oxygen availability (Figure 1). Steep oxygen concentration gradients were measured in the vicinity of the biofilm, with parts of the biofilm experiencing oxygen concentrations of $0.2 \mathrm{mg} \mathrm{l}^{-1}$ or less (Figure 1). These measurements are concordant with the transcriptomic analysis of biofilm bacteria that provides direct biological evidence of oxygen limitation (Figure 3B, Table 3). The following describes our physical understanding of the concentration gradients in this particular biofilm system. In the aerobic layer, both oxygen and glucose are consumed. Once the oxygen has been depleted, utilization of glucose stops. Abundant glucose, approximately $125 \mathrm{mg} \mathrm{l}^{-1}$, is predicted to be available at the bottom of the biofilms studied in this investigation. 
We note that $P$. aeruginosa is unable to ferment glucose and no arginine was present, precluding fermentative growth $[33,34]$. No alternative electron acceptor, such as nitrate, was added to the medium used in these studies. Therefore, growth by denitrification was also precluded. The expression of genes associated with denitrification in the biofilm (Figure 3D, Table 3) may have been a response to oxygen limitation. In summary, once oxygen was depleted in this system, one would predict that growth would cease.

\section{Biofilm harbors slowly-growing or non-growing bacteria}

We hypothesize that oxygen limitation in $P$. aeruginosa drip-flow biofilms resulted in slow growth or lack of growth of many of the bacteria in the biofilm. The expression of an inducible GFP was focused in a sharply demarcated band immediately adjacent to the oxygen source. This band represented approximately $38 \%$ of the biofilm, indicating that as much as $62 \%$ of the biofilm could be anoxic and anabolically inactive. Because alternative fermentable substrates or electron acceptors were absent, oxygen limitation is expected to be sufficient to lead to arrested growth in anoxic regions of the biofilm. This interpretation is qualitatively consistent with previous studies of oxygen availability and spatial patterns of physiological activity in some other $P$. aeruginosa biofilms [12-14,35,36].

Transcriptomic data show that the biofilm exhibited stationary phase character (Figure 3E). This is evident in the pronounced expression of $r m f$, a stationaryphase inhibitor of ribosome function [37], $\operatorname{cspD}$, a stationary-phase inhibitor of replication [38], and rpoS, a stationary-phase sigma factor [27]. In a previous investigation, we independently reported the elevated expression of rpoS in P. aeruginosa biofilms [39]. A gene associated with early exponential phase growth, fis, was expressed at relatively low levels, consistent with very slow growth. Our estimate of an average specific growth rate of $0.08 \mathrm{~h}^{-1}$ is approximately ten percent of the specific growth rate of $P$. aeruginosa in this medium of $0.74 \mathrm{~h}^{-1}$. Colony biofilms of a mucoid strain of $P$. aeruginosa had a reported specific growth rate that was two percent of the maximum specific growth rate in that system [13].

Here we consider two alternative conceptual models for growth and activity within the biofilm. These models attempt to address the microscale heterogeneity that is obviously present and which the transcriptional analysis is incapable of resolving. Both of these conceptual models view the biofilm as having two layers of differing growth rates. In the first model, an aerobic layer representing the upper $40 \%$ of the biofilm grows at $0.2 \mathrm{~h}^{-1}$ while the bottom layer has a specific growth rate of zero. The population average growth rate $\left(0.4^{*} 0.2 \mathrm{~h}^{-1}+\right.$
$0.6^{*} 0 \mathrm{~h}^{-1}$ ) would be $0.08 \mathrm{~h}^{-1}$. In the second model, an aerobic layer representing the upper $40 \%$ of the biofilm grows at $0.08 \mathrm{~h}^{-1}$ while the bottom layer has a specific growth rate of zero. The population average growth rate would be $0.032 \mathrm{~h}^{-1}$. We believe that the second model is the more realistic. The transcriptome obtained in this study does not represent the average behavior of the biofilm. It reflects rather the activities of the transcriptionally-active subpopulation, which is the aerobic upper layer. Localized gene expression measurements performed by microdissection and PCR show that the rpoS transcript is more abundant in the upper layer of the biofilm compared to the middle or bottom layers $[10,11]$. This confirms that the "active" cells in the biofilm are in fact in a stationary phase-like state and that the inactive cells are depleted of most mRNA.

\section{Transcriptional profiling of biofilms - stress responses and quorum sensing}

The same approach of comparing ranks of selected genes indicative of specific physiological activities was applied to examine oxidative stress, copper stress, efflux pump activities, and quorum sensing in drip-flow biofilms.

The expression levels, as quantified by transcript rank, of five genes associated with oxidative stress [40-42] were not in general elevated in reference to the comparators (Figure 5A). The only possible exception, a putative glutathione peroxidase (PA2826), is difficult to interpret clearly since this gene is also induced under copper stress (see the next paragraph). Thus we conclude that no unusual oxidative stress is occurring.

We noticed that several genes associated with copper stress, as reported by Teitzel et al. [20], were highly expressed in drip-flow biofilms (Figure 5B). The nominal copper concentration in $\mathrm{PBM}$ is $0.16 \mu \mathrm{M}$, which is much less than the $10 \mathrm{mM}$ Teitzel et al. used. We identified another data set, that of Love and co-workers [17], in which an acetate minimal medium was supplemented with trace elements including $\mathrm{Cu}$ at a final concentration of $2.9 \mu \mathrm{M}$. Copper stress genes were highly expressed in this case as well. We therefore suggest that micro molar concentrations of copper are sufficient to induce a copper stress response when $P$. aeruginosa is grown in minimal media.

Efflux pumps were not up-regulated in $P$. aeruginosa biofilms in general (Figure 5C). The one instance of obvious high level expression, PA3523, is associated with copper stress [20].

Three different laboratories have published data on the set of genes regulated by homoserine lactone quorum sensing in $P$. aeruginosa [43-45]. We selected a consensus subset of seven of these genes that are more highly expressed under conditions of active quorum 


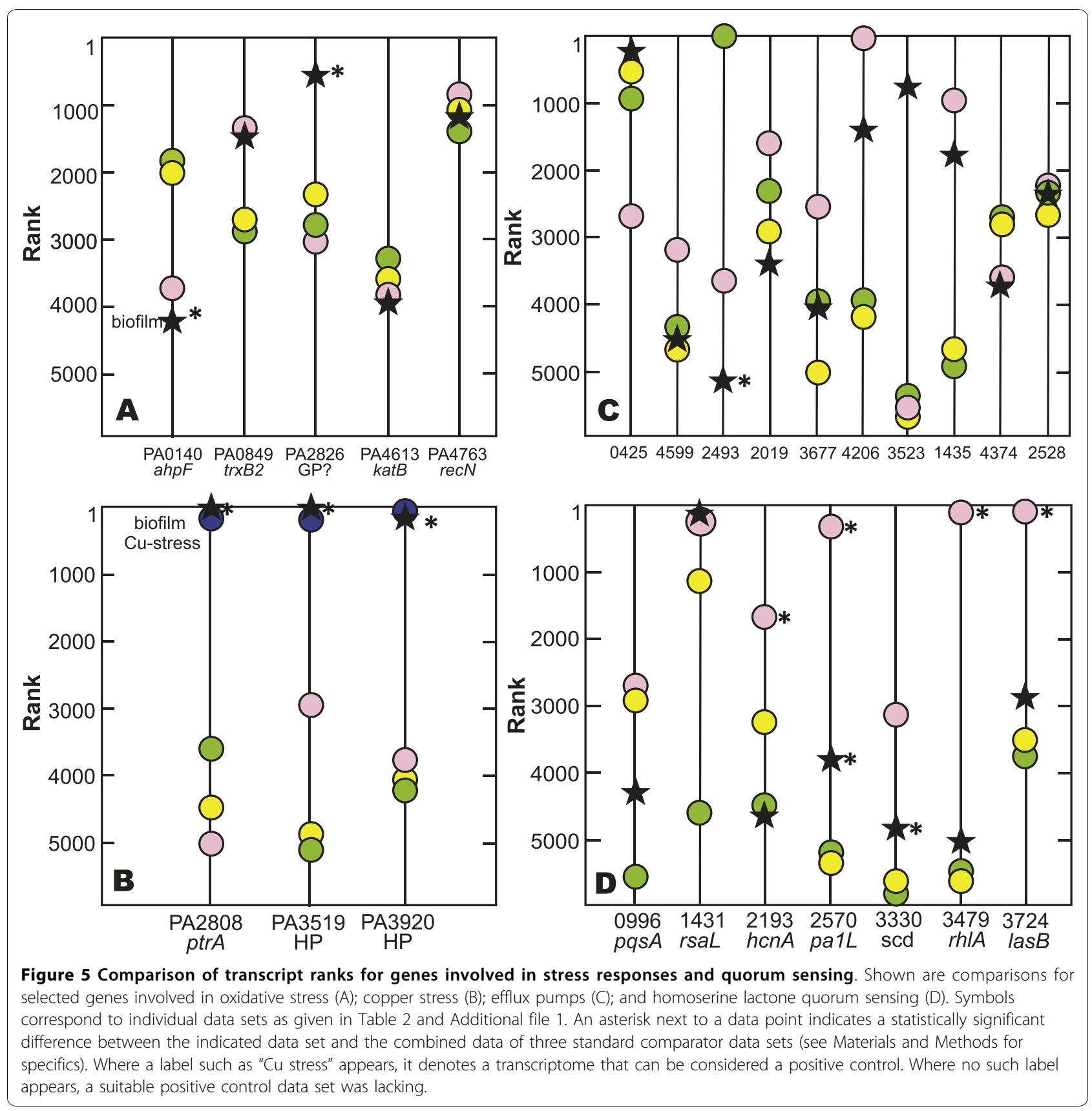

sensing and compared the drip-flow biofilm transcriptome to the standard reference data sets (Figure 5D). The biofilm rank was relatively low for all but one of these genes, PA1431 or rsaL. Though rsaL is itself quorum sensing activated, the $r s a L$ gene product is a negative regulator that represses many other quorumsensing activated genes [46]. Thus the high level expression of $r s a L$ may be consistent with repression of many of the other genes shown in Figure 5D. These data show, surprisingly, that homoserine lactone quorum sensing is not active in these drip-flow biofilms.
To further demonstrate the potential for differences in transcript ranks to serve as indices of specific physiological activities, homoserine lactone quorum sensing was examined in a fashion analogous to that described above for glucose (Figure 4A) and growth rate (Figure 3F). The eight quorum sensing positive samples plotted in Figure 4B are planktonic cultures with optical densities greater than 2.0. The 10 quorum sensing negative samples in this figure are either from quorum sensing deficient mutants or planktonic cultures of very low optical density. The drip-flow biofilm data points 
clearly do not group with quorum sensing positive benchmarks (Figure 4B).

Quorum sensing has been associated with biofilm development in $P$. aeruginosa by many investigators [47-50], so our finding that this communication system is silent in three-day old drip-flow biofilms seems at odds with the literature. This result is internally consistent, however, with the elevated expression of two negative regulators of quorum sensing, rsaL [46] and $a \lg R$, another repressor of quorum sensing [51]. The $a \lg R$ gene transcript ranked 252 in drip-flow biofilms and 1251 in the same comparator data sets used to compile Table 3. We speculate that quorum sensing may have been active at an earlier stage of biofilm formation in the drip-flow reactor.

\section{Transcriptional profiling - biofilm extracellular matrix genes}

Extracellular polysaccharides and proteins are common constituents of the biofilm matrix. There are four putative or known polysaccharide biosynthetic operons in $P$. aeruginosa [52]. Both pel and psl genes were expressed in the biofilm while alginate biosynthetic genes were not. Only the pel genes were up-regulated in biofilms compared to the three planktonic controls (Figure 6A). The low level of expression of $\operatorname{alg} D$ in the drip-flow biofilm is consistent with prior reports that alginate is not an important constituent of PAO1 biofilms [53]. Our transcriptomic data suggest that the pel and psl polysaccharides may be important constituents of the extracellular matrix of drip-flow biofilms while alginate is unimportant (Figure 6A). The rank of the $c d r A$ gene, a recently described adhesin that interacts with the psl polysaccharide [54], was not much different in drip-flow biofilms and planktonic comparators.

Genes associated with the elaboration of type IV pili were strongly expressed in drip-flow biofilms (Figure $6 \mathrm{~B})$. This has led us to speculate that these extracellular proteinaceous appendages contribute to the mechanical stability of the biofilm rather than motility, perhaps by binding to extracellular DNA $[55,56]$.

\section{Transcriptional profiling - independent identification of upregulated genes in biofilms}

All of the preceding analyses were predicated using $a$ priori identification of a set of genes associated with discrete physiological conditions. The comparison of transcript ranks can also be used to identify genes that are differentially regulated between the drip-flow biofilm data set and planktonic comparator data sets. Table 3 reports the 100 genes that ranked more highly in the drip-flow biofilm than in the comparator data set, by fold-changes in rank ranging from 8 to more than 100 . Some of the salient features of this list are genes associated with oxygen limitation (27 genes), copper stress (12 genes), bacteriophage Pf1 (10 genes), denitrification (8 genes), ethanol metabolism (4 genes), and three genes involved in type IV fimbrial biogenesis. Seven of the genes listed in Table 3 (PA0200, PA0409, PA0713, PA1174, PA3309, PA3572, PA5446) appear on the

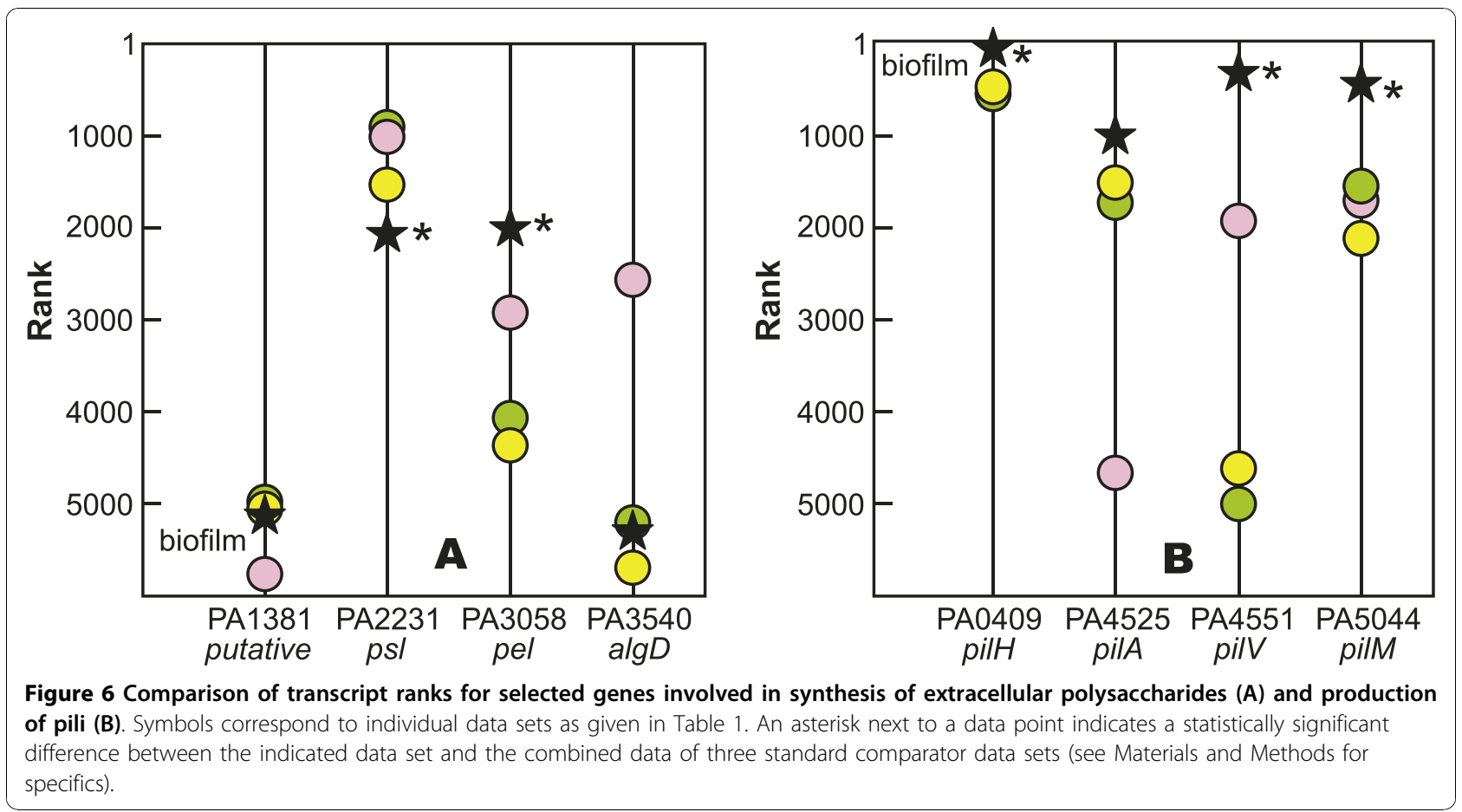


consensus list of gene transcripts upregulated in P. aeruginosa biofilms reported by Patell et al [7].

\section{Biological basis of biofilm antibiotic tolerance}

$P$. aeruginosa strain PAO1 formed biofilms in the drip-flow reactor that were poorly killed by tobramycin or ciprofloxacin. This result is concordant with many previous investigations of antibiotic susceptibility of $P$. aeruginosa biofilms developed in other in vitro systems $[12,13,43,57-82]$.

A plausible and long-standing explanation for reduced antibiotic susceptibility in biofilms is that nutrient limitation leads to slow growth or stationary phase existence for many of the cells in a biofilm, reducing their antimicrobial susceptibility [63,83-85]. This mechanism is consistent with all of our data. Multiple lines of evidence support oxygen limitation and arrested growth in drip-flow biofilms: oxygen concentration gradients (Figure 1), expression of genes associated with oxygen limitation (Figure 3B, Table 3) and stationary phase existence (Figure 3E), and stratified patterns of protein synthetic activity (Figure 2). In a previous study using a different in vitro biofilm model, we reported that oxygen limitation could account for 70 percent or more of the protection from six antibiotics observed in P. aeruginosa colony biofilms [12]. A recent report showed that ciprofloxacin and tetracycline preferentially killed the metabolically active subpopulation in $P$. aeruginosa biofilms [65].

Oxygen limitation is known to occur in vivo in cystic fibrosis patients [86]. Further, molecular biological evidence suggests that $P$. aeruginosa in the cystic fibrosis lung experiences anaerobic conditions [87]. In an investigation of in situ growth rates of $P$. aeruginosa obtained from chronic lung infections, approximately $11 \%$ of cells were determined to be in a non-growing stationaryphase based on their ribosome content [88]. The average specific growth rate of the growing bacterial cells was $0.31 \mathrm{~h}^{-1}$. This shows that a non-growing population may be relevant in vivo, though it suggests that the population of bacteria in the infected lung were overall more active than we describe here for drip-flow biofilms.

\section{Heterogeneity within the biofilm}

Here we remark on the "averaging" that occurs when the entire biofilm is mashed up and extracted RNA is analyzed. This method mixes together the RNA from transcriptionally active cells in the aerobic upper layer of the biofilm with RNA from inactive bacteria in the lower layers of the biofilm. The result is not a simple average of the activities of the two layers because there is so much less mRNA in the inactive bacteria. Indeed, the inactive bacteria may contribute little to the overall microarray signal. For this reason, the transcriptome that has been examined in this work may best be thought of as representing the transcriptionally-active supopulation of bacteria rather than an average of the entire biofilm population.

A recently described laser capture microdissection technique provides a direct experimental approach for quantifying the amount of specific RNA sequences in distinct regions of the biofilm $[10,11]$. This method begins with cryoembedding an intact biofilm and preparing frozen cross sections. Small user-defined areas of the cross section can be physically removed and amplified by PCR to detect specific transcripts. Application of this approach to drip-flow $P$. aeruginosa biofilms has revealed that the upper layer of the biofilm is enriched in mRNA compared to the lower layers $[10,11]$. For example, in drip-flow biofilms the number of RNA copies of the housekeeping gene $a c p P$ was approximately 60 times smaller at the bottom of the biofilm compared to the top [10]. For the rhlR transcript the difference between top and bottom was approximately 30 -fold [11].

\section{Utility of ranked transcriptome analysis}

Conventional transcriptional profiling is applied to paired samples and allows for the discovery of genes that are differentially regulated between the two samples. For example, comparing the transcriptomes of samples grown at two different temperatures or in the presence and absence of a signaling molecule leads directly to the identification of genes regulated by temperature or by the specific signal chemistry. This is the usual usage of transcriptional profiling technology.

In this investigation, we sought to use transcriptional profiling to provide insight about the physiological activities of a single sample. Rather than chronicling the differences between two conditions (e.g., biofilm and planktonic), we wanted to ask and answer the question "What is the transcriptionally active biofilm cell doing?" To do this, we ranked the transcriptome, which makes manifest the priorities of the cell, at least at the transcriptional level. To interpret this ladder of genes, we independently identified from the literature sets of genes as markers of particular physiological activities and then compared the ranks of these genes to the ranks in several planktonic comparator transcriptomes. As the public database of transcriptional data expands, this approach becomes more and more feasible and powerful. Our effort is a preliminary one that surely will benefit from many improvements.

\section{Conclusions}

The physiological activities of mature $P$. aeruginosa biofilms were elucidated by integrating existing knowledge of gene functions and transcriptional responses, a public database of transcriptomic data, a whole-biofilm 
transcriptome, and other chemical and biological assay results. The biofilm was found to be limited for oxygen, growing slowly, and exhibiting stationary phase character.

\section{Methods}

\section{Bacterial strains and growth conditions}

Pure cultures of the Pseudomonas aeruginosa strain PAO1 were used for all experiments involving antibiotic treatment. Experiments investigating patterns of protein synthetic activity, used strain PAO1 (pAB1), containing a plasmid with an IPTG inducible gene for expression of a stable GFP. The vector control $P$. aeruginosa PAO1 (pPMF54) contained the same plasmid as pAB1 without the GFP gene. P. aeruginosa was grown in Pseudomonas basal mineral medium [89] (PBM) containing $0.2 \mathrm{~g} \mathrm{l}^{-1}$ glucose for experiments measuring growth or antibiotic susceptibility. Inocula were grown in the same medium containing $1 \mathrm{~g} \mathrm{l}^{-1}$ glucose. Cultures were prepared in shake flasks at $37^{\circ} \mathrm{C}$ with $200 \mathrm{rpm}$ agitation. Tobramycin sulfate was obtained from Sigma-Aldrich, ciprofloxacin hydrochloride was a gift of the Bayer Corporation. Viable cell numbers were determined by colony formation on tryptic soy agar (TSA; Becton Dickinson).

\section{Preparation of biofilms}

Biofilms were grown in drip-flow reactors as described [36] using PBM supplemented with $0.2 \mathrm{~g} \mathrm{l}^{-1}$ glucose. Drip-flow reactors consisted of four parallel chambers that were covered with polycarbonate windows containing septa for the introduction of media using 22 gauge needles, and a filtered air vent. Media was pumped into the chambers at a flow rate of $60 \mathrm{ml} \mathrm{h}^{-1}$, dripping onto the stainless steel slides $(8.5 \mathrm{~cm} \times 1.3 \mathrm{~cm})$ placed in the chambers. The reactors were placed on a stand inclined at $10^{\circ}$ from horizontal and PBM would flow the length of the coupon and drain from the reactor. The reactors were inoculated by adding $1 \mathrm{ml}$ of an overnight culture to $15 \mathrm{ml}$ of fresh PBM used to cover the slides (inoculum $\left.\mathrm{OD}_{600} \approx 0.3\right)$ in PBM $\left(1 \mathrm{~g} \mathrm{l}^{-1}\right.$ glucose $)$. The reactor was sealed by clamping the effluent tubes and the inoculum was allowed to sit in the reactor for 18-24 h on a level surface. After the inoculation period, the reactor was inclined and flow was initiated. The entire dripflow reactor was kept in a $37^{\circ} \mathrm{C}$ incubator. Medium flowing from outside the incubator was warmed by passing the silicone tubing through a grooved aluminum block kept in the incubator. The biofilms were grown in the drip flow reactors for 72 hours after the static inoculation phase.

\section{Biofilm protein synthetic activity patterns}

P. aeruginosa PAO1 (pAB1) biofilms were grown for 72 hours in drip flow reactors. The medium was then supplemented with $1 \mathrm{mM}$ IPTG and flow continued for
$4 \mathrm{~h}$. After this induction period, biofilm-covered slides were removed from the reactor and cryo-embedded in Tissue-Tek O.C.T. (VWR Scientific). Cryo-embedded biofilms were cryo-sectioned, and examined by confocal laser scanning microscopy with a Leica TCS NT with excitation at $488 \mathrm{~nm}$ and emission filter of 500 $530 \mathrm{~nm}$. Dimensions of the biofilm and the GFP-expressing zone were determined by image analysis using Scion Image software (Scion). Some specimens were counterstained with rhodamine B following IPTG induction of the GFP. In these cases, rhodamine B was introduced into the medium at a concentration of $5 \mu \mathrm{g} \mathrm{ml}^{-1}$ for $30 \mathrm{~min}$. The biofilms were then rinsed with fresh medium for $30 \mathrm{~min}$ before cryo-embedding.

\section{Oxygen concentrations in biofilms}

Oxygen concentration profiles in biofilms were measured with microelectrode technology described in detail elsewhere $[90,91]$. The microelectrode manipulator was placed inside the incubator so that the measurements could be made at $37^{\circ} \mathrm{C}$.

\section{Antibiotic susceptibility of biofilms}

After 72 hours of growth in the absence of antibiotic, the desired antibiotic was added to the growth medium, and the flow continued for an additional 12 hours. Tobramycin was applied at $10 \mu \mathrm{g} \mathrm{ml}^{-1}$ and ciprofloxacin at $1.0 \mu \mathrm{g} \mathrm{ml}^{-1}$. After treatment the stainless steel coupons were removed from the reactor and the number of viable cells was determined by scraping the biofilms into $9 \mathrm{ml}$ of phosphate buffer ( $\mathrm{pH} 7.2,1.4 \mathrm{mM}$ ) and homogenizing for $1 \mathrm{~min}$. The resulting cell suspensions were serially diluted and plated on TSA. Killing was reported as a $\log$ reduction. The $\log$ reduction was calculated relative to the cell count at time zero. Experiments were performed at least in triplicate.

\section{Re-suspended biofilm and planktonic susceptibility}

The antibiotic susceptibility of log phase $\left(\mathrm{OD}_{600} 0.030\right.$ 0.08 ) and re-suspended biofilms of $P$. aeruginosa was determined. One milliliter of an overnight culture of $P$. aeruginosa $\mathrm{PAO} 1$ was sub-cultured into $29 \mathrm{ml}$ of $\mathrm{PBM}$ $\left(1 \mathrm{~g} \mathrm{l}^{-1}\right.$ glucose $)$ and grown overnight with agitation $\left(37^{\circ} \mathrm{C}, 200 \mathrm{rpm}\right)$ prior to exposure to antibiotics. One milliliter aliquots from the overnight cultures were mixed with $29 \mathrm{ml}$ of fresh PBM (1 $\mathrm{g} \mathrm{l}^{-1}$ glucose) containing antibiotics (tobramycin at $10 \mu \mathrm{g} \mathrm{ml}^{-1}$ or ciprofloxacin at $1.0 \mu \mathrm{g} \mathrm{ml}^{-1}$ ) to start treatment. Biofilms $(72 \mathrm{~h})$ scraped from coupons, were homogenized in phosphate buffer for 1 minute using a tissue homogenizer and re-suspended in $30 \mathrm{ml}$ of PBM ( $1 \mathrm{~g} \mathrm{l}^{-1}$ glucose) with antibiotics (as above), to yield a cell density of $3.0 \times 10^{7}$ cells ml$^{-1}$. After suspension in antibiotic containing media, cultures were placed in an orbital shaking incubator at $37^{\circ} \mathrm{C}$ and 
sampled over the course of 12 hours. The resulting cell suspensions were serially diluted and viable bacterial numbers were determined by plating on TSA.

\section{Preparation of biofilms for RNA extraction}

Biofilms were grown in the drip flow reactor for either 72 $\mathrm{h}(\mathrm{n}=3)$ or $84 \mathrm{~h}(\mathrm{n}=3)$. Data from these two time points were pooled. Biofilms were scraped directly into $1 \mathrm{ml}$ of RNAlater (Ambion). Clumps were dispersed by repeated pippetting with a micro-pipette and the recovered biofilms were stored at $4^{\circ} \mathrm{C}$ for one day prior to removal of the RNAlater ${ }^{\circ}$ by centrifugation $\left(15 \mathrm{~min}, 4^{\circ} \mathrm{C}\right.$, and $\left.14000 \mathrm{~g}\right)$ and freezing of the biofilm cells at $-70^{\circ} \mathrm{C}$.

\section{RNA extraction}

Biofilm cells were thawed on ice and re-suspended in $300 \mu \mathrm{l}$ of $1 \mathrm{mg}$ lysozyme $\mathrm{ml}^{-1}$ Tris-EDTA buffer (TE; 10 $\mathrm{mM}$ Tris, $1 \mathrm{mM}$ EDTA, $\mathrm{pH}$ 8.0) and divided into three aliquots. Each aliquot was sonicated for $15 \mathrm{~s}$, and incubated at room temperature for 15 minutes. RNA was extracted with an $\mathrm{RNeasy}^{\circ}$ mini kit (Qiagen Sciences) with on column DNA digestion (DNA Free kit; Ambion) the three aliquots were combined onto a single column. RNA concentrations and purity were determined by measuring the absorbance at $260 \mathrm{~nm}, 280 \mathrm{~nm}$ and 230 nm using a NanoDrop ND-1000 spectrophotometer (NanoDrop Technologies). RNA quality was evaluated using the RNA 6000 NanoChip assay on a 2100 Bioanalyzer (Agilent Technologies). The $23 \mathrm{~s}: 16 \mathrm{~s}$ rRNA ratio for all samples used exceeded 2.0.

\section{Microarray hybridization}

Isolated total RNA $(10 \mu \mathrm{g})$ was reverse-transcribed, fragmented using DNAseI and biotin end-labeled according to Affymetrix's Prokaryotic Target Labeling Protocol (GeneChip Expression Analysis Technical Manual; November, 2004). For each Pseudomonas genome array (\#900339, Affymetrix), $4.5 \mu \mathrm{g}$ of labeled fragmented cDNA was hybridized to the arrays at $50^{\circ} \mathrm{C}$ for $16 \mathrm{~h}$ with constant rotational mixing at $60 \mathrm{rpm}$. Washing and staining of the arrays was performed using the Affymetrix GeneChip Fluidics Station 450. Arrays were scanned using an Affymetrix GeneChip Scanner 7 $\mathrm{G}$ and GCOS software version 1.4. The MAS5 signal intensity for all the probes on the chip was determined.

\section{Comparison of rankings}

Microarray data from studies of planktonic bacteria listed in Table 2 were used to interpret the data from our own microarrays. The available signal intensity data for all the probes on each microarray were downloaded from the NIH's gene expression omnibus (GEO) database and imported into Microsoft Excel along with our own microarray signal intensities. Our microarray data have been deposited in NCBI's Gene Expression Omnibus [92] and are accessible through GEO Series accession number GSE22164. For all of these data sets the probe intensities from each microarray were sorted from highest to lowest and the ranking for each of the loci of interest was taken as an average of the ranking from individual replicates.

Three of these data sets were repeatedly used as comparators; results of these particular comparators appear on most of the graphs in Figures 3, 5, and 6 and are the basis of the averaged comparator ranks reported in Table 3 . These three data sets were the $20 \%$ oxygen condition of Alvarez-Ortega and Harwood [15]; the untreated control of Teitzel et al [20]; and the untreated control of Nalca et al. [18]. The first two were reported to be exponential phase cultures and the latter was described as an early stationary phase culture.

To compile the list of genes up-regulated in drip-flow biofilms, the average rank in the drip-flow biofilm data set was compared to the average rank in the three comparator data sets named above. The fold change in the rank between the biofilm and the planktonic comparators was calculated and the 100 genes with the highest fold change were tabulated.

\section{Statistics}

Claims of statistically significant differences in transcriptome ranks are based on 109 individual two sample Welch $t$-tests (i.e. heterogeneous variances are modeled) on the ranks of each sample using a familywise false discovery rate of 5\% [93]. These analyses are similar to the non-parametric Friedman and MackSkillings rank tests used for the analysis of microarray data [94-97]. This approach is more conservative than the pooled $t$-test analysis of rank data advocated by Conover [98] since the Welch $t$-test models the obvious heteroscedastic variability between the ranks of the drip flow biofilm transcriptome and the ranks of the comparator transcriptomes.

\section{Additional material}

Additional file 1: $P$. aeruginosa transcriptional profiling data sets

used for comparison with colored symbol key.

\section{Acknowledgements}

This work was supported by NIH awards R01GM067245-02 and R01DC04173-01A1 and by an award from the W. M. Keck Foundation. Microscopy was facilitated by equipment made possible by an award from the M. J. Murdock Charitable Trust. Support for the Montana State University bioinformatics core (NCRR INBRE award P20 RR016455, COBRE award P20 RR020185, NSF IGERT award DGE-0654336, NSF EPSCOR award EPS-0701906) and genomics core (NCRR INBRE award P20 RR016455) is gratefully acknowledged. 


\section{Author details}

${ }^{1}$ Center for Biofilm Engineering and Department of Chemical and Biological Engineering, P. O. Box 173980 Montana State University - Bozeman Bozeman, Montana 59717-3980, USA. ${ }^{2}$ Halliburton, P.O. Box 439, Pinedale, WY 82941, USA. ${ }^{3} 1658$ Eligio Lane, Davis, CA 95618, USA. ${ }^{4}$ Center for Genomic Sciences Allegheny Singer Research Institute 320 E. North Ave. Pittsburgh, PA 15212, USA. ${ }^{5}$ Bioinformatics Core, Montana State University, Bozeman, Montana, USA

\section{Authors' contributions}

JF carried out the transcriptional profiling studies and helped to draft the manuscript. LR made measurements of biofilm antibiotic susceptibility and protein synthetic activity. BP assisted with microscopy. FR performed the oxygen microelectrode measurements. GE participated in the design of the study and formulation of hypotheses. AP performed the statistical analyses. AM performed the bioinformatic analysis that generated Figure 4. PS conceived the experimental and analytical approaches, supervised laboratory work and drafted the manuscript. All authors read and approved the final manuscript.

Received: 27 August 2010 Accepted: 17 November 2010 Published: 17 November 2010

\section{References}

1. Stewart PS, Franklin MJ: Physiological heterogeneity in biofilms. Nat Rev Microbiol 2008, 6:199-210

2. Whiteley M, Bangera MG, Bumgarner RE, Parsek MR, Teitzel GM, Lory S, Greenberg EP: Gene expression in Pseudomonas aeruginosa biofilms. Nature 2001, 413:860-864

3. An D, Parsek MR: The promise and peril of transcriptional profiling in biofilm communities. Curr Opin Microbiol 2007, 10:292-296.

4. Hentzer M, Eberl L, Givskov M: Transcriptome analysis of Pseudomonas aeruginosa biofilm development: anaerobic respiration and iron limitation. Biofilms 2005, 2:37-61.

5. Waite R, Paccanaro A, Papakonstantinopoulou A, Hurst J, Saqi M, Littler E, Curtis M: Clustering of Pseudomonas aeruginosa transcriptomes from planktonic cultures, developing and mature biofilms reveals distinct expression profiles. BMC Genomics 2006, 7:162.

6. Waite RD, Papakonstantinopoulou A, Littler E, Curtis MA: Transcriptome analysis of Pseudomonas aeruginosa growth: Comparison of gene expression in planktonic cultures and developing and mature biofilms. J Bacteriol 2005, 187:6571-6576.

7. Patell S, Gu M, Davenport P, Givskov M, Waite RD, Welch M: Comparative microarray analysis reveals that the core biofilm-associated transcriptome of Pseudomonas aeruginosa comprises relatively few genes. Environ Microbiol Rep 2010, 2:440-448.

8. Mah T-F, OToole GA: Mechanisms of biofilm resistance to antimicrobial agents. Trends Microbiol 2001, 9:34-39.

9. Ochsner UA, Wilderman PJ, Vasil Al, Vasil ML: GeneChip expression analysis of the iron starvation response in Pseudomonas aeruginosa: identification of novel pyoverdine biosynthesis genes. Mol Microbiol 2002, 45:1277-1287.

10. Lenz AP, Williamson KS, Franklin MJ: Localized gene expression in Pseudomonas aeruginosa biofilms. Appl Environ Microbiol 2008, 74:4463-4471.

11. Perez-Osorio AC, Williamson KS, Franklin MJ: Heterogeneous rpoS and rhIR mRNA levels and $16 \mathrm{~S}$ rRNA/rDNA (rRNA gene) ratios within Pseudomonas aeruginosa biofilms, sampled by laser capture microdissection. J Bacteriol 2010, 192:2991-3000

12. Borriello G, Werner E, Roe F, Kim AM, Ehrlich GD, Stewart PS: Oxygen limitation contributes to antibiotic tolerance of Pseudomonas aeruginosa in biofilms. Antimicrob Agents Chemother 2004, 48:2659-2664.

13. Walters MC, Roe F, Bugnicourt A, Franklin MJ, Stewart PS: Contributions of antibiotic penetration, oxygen limitation, and low metabolic activity to tolerance of Pseudomonas aeruginosa biofilms to ciprofloxacin and tobramycin. Antimicrob Agents Chemother 2003, 47:317-323.

14. Werner E, Roe F, Bugnicourt A, Franklin MJ, Hayden A, Molin S, Pitts B, Stewart PS: Stratified growth in Pseudomonas aeruginosa biofilms. Appl Environ Microbiol 2004, 70:6188-6196.
15. Alvarez-Ortega C, Harwood CS: Responses of Pseudomonas aeruginosa to low oxygen indicate that growth in the cystic fibrosis lung is by aerobic respiration. Mol Microbiol 2007, 65:153-165.

16. Cirz RT, O'Neill BM, Hammond JA, Head SR, Romesberg FE: Defining the Pseudomonas aeruginosa SOS response and its role in the global response to the antibiotic ciprofloxacin. J Bacteriol 2006, 188:7101-7110.

17. Muller JF, Stevens AM, Craig J, Love NG: Transcriptome analysis reveals that multidrug efflux genes are upregulated to protect Pseudomonas aeruginosa from pentachlorophenol stress. Appl Environ Microbiol 2007 73:4550-4558.

18. Nalca Y, Jansch L, Bredenbruch F, Geffers R, Buer J, Haussler S: Quorumsensing antagonistic activities of azithromycin in Pseudomonas aeruginosa PAO1: a global approach. Antimicrob Agents Chemother 2006, 50:1680-1688.

19. Son MS, Matthews WJJ, Kang Y, Nguyen DT, Hoang TT: In vivo evidence of Pseudomonas aeruginosa nutrient acquisition and pathogenesis in the lungs of cystic fibrosis patients. Infect Immun 2007, 75:5313-5324.

20. Teitzel GM, Geddie A, De Long SK, Kirisits MJ, Whiteley M, Parsek MR: Survival and growth in the presence of elevated copper: transcriptional profiling of copper-stressed Pseudomonas aeruginosa. J Bacteriol 2006, 188:7242-7256.

21. Tralau T, Vuilleumier S, Thibault C, Campbell BJ, Hart CA, Kertesz MA: Transcriptomic analysis of the sulfate starvation response of Pseudomonas aeruginosa. J Bacteriol 2007, 189:6743-6750.

22. Zheng P, Sun J, Geffers R, Zeng A-P: Functional characterization of the gene PA2384 in large-scale gene regulation in response to iron starvation in Pseudomonas aeruginosa. J Biotechnol 2007, 132:342-352.

23. Hancock REW, Carey AM: Protein D1: a glucose-inducible, pore-forming protein from the outer membrane of Pseudomonas aeruginosa. FEMS Microbiol Lett 1980, 8:105-109.

24. Trunk K, Benkert B, Quack N, Munch R, Scheer M, Garbe J, Trost M, Wehland J, Buer J, Jahn M, et al: Anaerobic adaptation in Pseudomonas aeruginosa: definition of the Anr and Dnr regulons. Environ Microbiol 2010, 12:1719-1723.

25. Filiatrault MJ, Wagner VE, Bushnell D, Haidaris CG, Iglewski BH, Passador L: Effect of anaerobiosis and nitrate on gene expression in Pseudomonas aeruginosa. Infect Immun 2005, 73:3764-3772.

26. Ball CA, Osuna R, Ferguson KC, Johnson RC: Dramatic changes in Fis levels upon nutrient upshift in Escherichia coli. J Bacteriol 1992, 174:8043-8056.

27. Fujita $M$, Tanaka $K$, Takahashi $H$, Amemura A: Transcription of the principal sigma-factor genes, rpoD and rpoS, in Pseudomonas aeruginosa is controlled according to the growth phase. Mol Microbiol 1994, 13:1071-1077.

28. Schuster M, Hawkins AC, Harwood CS, Greenberg EP: The Pseudomonas aeruginosa RpoS regulon and its relationship to quorum sensing. Mo Microbiol 2004, 51:973-985.

29. Yuste L, Hervas AB, Canosa I, Tobes R, Jimenez Jl, Nogales J, PerezPerez MM, Santero E, Diaz E, Ramos JL, et al: Growth phase-dependent expression of the Pseudomonas putida KT2440 transcriptional machinery analyzed with a genome-wide DNA microarray. Environ Microbiol 2006, 8:165-177.

30. Williamson K, McCarty PL: A model of substrate utilization by bacterial films. J Water Pollut Con F 1976, 48:9-24.

31. Stewart PS: Diffusion in biofilms. J Bacteriol 2003, 185:1485-1491,

32. Characklis WG: Energetics and stoichiometry. Biofilms New York: John Wiley \& Sons; 1990.

33. Carlson CA, Ingraham JL: Comparison of denitrification by Pseudomonas stutzeri, Pseudomonas aeruginosa, and Paracoccus denitrificans. Appl Environ Microbiol 1983, 45:1247-1253.

34. Vander Wauven C, Pierard A, Kley-Raymann M, Haas D: Pseudomonas aeruginosa mutants affected in anaerobic growth on arginine: Evidence for a four-gene cluster encoding the arginine deiminase pathway. J Bacteriol 1984, 160:928-934.

35. Xu KD, McFeters GA, Stewart PS: Biofilm resistance to antimicrobial agents. Microbiology 2000, 146:547-549.

36. Xu KD, Stewart PS, Xia F, Huang C-T, McFeters GA: Spatial physiological heterogeneity in Pseudomonas aeruginosa biofilm is determined by oxygen availability. Appl Environ Microbiol 1998, 64:4035-4039.

37. Wada A, Igrashi K, Yoshimura S, Aimoto S, Ishihama A: Ribosome modulation factor: Stationary growth phase-specific inhibitor of 
ribosome function from Escherichia coli. Biochem Biophys Res Commun 1995, 214:410-417.

38. Yamanaka K, Zheng W, Crooke E, Wang YH, Inouye M: $C s p D$, a novel DNA replication inhibitor induced during stationary phase in Escherichia coli. Mol Microbiol 2001, 39:1572-1584

39. Xu KD, Franklin MJ, Park C-H, McFeters GA, Stewart PS: Gene expression and protein levels of the stationary phase sigma factor, RpoS, in continously-fed Pseudomonas aeruginosa biofilms. FEMS Microbiol Lett 2001, 199:67-71.

40. Palma M, DeLuca D, Worgall S, Quadri LEN: Transcriptome Analysis of the Response of Pseudomonas aeruginosa to Hydrogen Peroxide. J Bacteriol 2004, 186:248-252

41. Salunkhe $P$, Topfer T, Buer J, Tummler B: Genome-wide transcriptional profiling of the steady-state response of Pseudomonas aeruginosa to hydrogen peroxide. J Bacteriol 2005, 187:2565-2572.

42. Small DA, Chang W, Toghrol F, Bentley WE: Comparative global transcription analysis of sodium hypochlorite, peracetic acid, and hydrogen peroxide on Pseudomonas aeruginosa. Appl Microbiol Biotechnol 2007, 76:1093-1105.

43. Hentzer M, Wu H, Andersen JB, Riedel K, Rasmussen TB, Bagge N, Kumar N, Schembri MA, Song Z, Kristofferson P, et al: Attenuation of Pseudomonas aeruginosa virulence by quorum sensing inhibitors. EMBO Journal 2003, 22:3803-3815.

44. Schuster M, Lostroh CP, Ogi T, Greenberg EP: Identification, timing, and signal specificity of Pseudomonas aeruginosa quorum-controlled genes: A transcriptome analysis. J Bacteriol 2003, 185:2066-2079.

45. Wagner VE, Bushnell D, Passador L, Brooks Al, Iglewski BH: Microarray analysis of Pseudomonas aeruginosa quorum-sensing regulons: Effects of growth phase and environment. J Bacteriol 2003, 185:2080-2095

46. Rampioni G, Schuster M, Greenberg EP, Bertani I, Grasso M, Venturi V, Zennaro E, Leoni L: RsaL provides quorum sensing homeostasis and functions as a global regulator of gene expression in Pseudomonas aeruginosa. Mol Microbiol 2007, 66:1557-1565.

47. Davies DG, Parsek MR, Pearson JP, Iglewski BH, Costerton JW, Greenberg EP: The involvement of cell-to-cell signals in the development of a bacterial biofilm. Science 1998, 280:295-298.

48. De Kievit TR, Iglewski BH, Marx S, Brown C: Quorum-sensing genes in Pseudomonas aeruginosa biofilms: Their role and expression patterns. Appl Environ Microbiol 2001, 67:1865-1873.

49. Sauer K, Camper AK, Ehrlich GD, Costerton W, Davies DG: Pseudomonas aeruginosa displays multiple phenotypes during development as a biofilm. J Bacteriol 2002, 184:1140-1154

50. Shrout JD, Chopp DL, Just CL, Hentzer M, Givskov M, Parsek MR: The impact of quorum sensing and swarming motility on Pseudomonas aeruginosa biofilm formation is nutritionally conditional. Mol Microbiol 2006, 62:1264-1277.

51. Morici LA, Carterson AJ, Wagner VE, Frisk A, Schurr JR, Höner zu Bentrup K, Hassett DJ, Iglewski BH, Sauer K, Schurr MJ: Pseudomonas aeruginosa algR represses the rhl quorum-sensing system in a biofilm-specific manner. $J$ Bacteriol 2007, 189:7752-7764.

52. Matsukawa M, Greenberg EP: Putative exopolysaccharide synthesis genes influence Pseudomonas aeruginosa biofilm development. J Bacteriol 2004, 186:4449-4456

53. Wozniak DJ, Wyckoff TJO, Starkey M, Keyser R, Azadi P, OToole GA, Parsek MR: Alginate is not a significant component of the extracellular polysaccharide matrix of PA14 and PA01 Pseudomonas aeruginosa biofilms. Proc Natl Acad Sci USA 2003, 100:7907-7912.

54. Borlee BR, Goldman AD, Murakami K, Samudrala R, Wozniak DJ, Parsek MR Pseudomonas aeruginosa uses a cyclic-di-GMP-regulated adhesin to reinforce the biofilm extracellular matrix. Mol Microbiol 2010, 75:827-842

55. Barken KB, Pamp SJ, Yang L, Gjermansen M, Bertrand JJ, Klausen M, Givskov M, Whitchurch CB, Engel JN, Tolker-Nielsen T: Roles of type IV pili, flagellum-mediated motility and extracellular DNA in the formation of mature multicellular structures in Pseudomonas aeruginosa biofilms. Environ Microbiol 2008, 10:2331-2343.
56. Jurcisek JA, Bakaletz LO: Biofilms formed by nontypeable haemophilus influenzae In vivo contain both double-stranded DNA and type IV pilin protein. J Bacteriol 2007, 189:3868-3875.

57. Stewart PS, Wattanakaroon W, Goodrum L, Fortun SM, McLeod BR: Electrolytic generation of oxygen partially explains electrical enhancement of tobramycin efficacy against Pseudomonas aeruginosa biofilm. Antimicrob Agents Chemother 1999, 43:292-296.

58. Borriello G, Richards L, Ehrlich GD, Stewart PS: Arginine or nitrate enhances antibiotic susceptibility of Pseudomonas aeruginosa in biofilms. Antimicrob Agents Chemother 2006, 50:382-384.

59. Bjarnsholt $T$, Jensen $P \varnothing$, Rasmussen $T B$, Christophersen $L$, Calum $H$, Hentzer M, Hougen H-P, Rygaard J, Moser C, Eberl L, et al: Garlic blocks quorum sensing and promotes rapid clearing of pulmonary Pseudomonas aeruginosa infections. Microbiology 2005, 151:3873-3880.

60. Anderson GG, Moreau-Marquis S, Stanton BA, O'Toole GA: In vitro analysis of tobramycin-treated Pseudomonas aeruginosa biofilms on cystic fibrosis-derived airway epithelial cells. Infect Immun 2008, 76:1423-1433.

61. Mah T-F, Pitts B, Pellock B, Walker GC, Stewart PS, OToole GA: A genetic basis for Pseudomonas aeruginosa biofilm antibiotic resistance. Nature 2003, 426:306-310

62. Field TR, White A, Elborn JS, Tunney MM: Effect of oxygen limitation on the in vitro antimicrobial susceptibility of clinical isolates of Pseudomonas aeruginosa grown planktonically and as biofilms. Eur J Clin Microbiol 2005, 24:677-687.

63. Evans DJ, Allison DG, Brown MRW, Gilbert P: Susceptibility of Pseudomonas aeruginosa and Escherichia coli biofilms towards ciprofloxacin: Effect of specific growth rate. J Antimicrob Chemother 1991, 27:177-184.

64. Zhang L, Mah T-F: Involvement of a novel efflux system in biofilmspecific resistance to antibiotics. J Bacteriol 2008, 190:4447-4452.

65. Pamp SJ, Gjermansen M, Johansen HK, Tolker-Nielsen T: Tolerance to the antimicrobial peptide colistin in Pseudomonas aeruginosa biofilms is linked to metabolically active cells, and depends on the pmr and mexAB-oprM genes. Mol Microbiol 2008, 68:223-240.

66. Tré-Hardy M, Vanderbist F, Traore H, Devleeschouwer MJ: In vitro activity of antibiotic combinations against Pseudomonas aeruginosa biofilm and planktonic cultures. Int J Antimicrob Agents 2008, 31:329-336.

67. Moriarty TF, Elborn JS, Tunney MM: Effect of $\mathrm{pH}$ on the antimicrobial susceptibility of planktonic and biofilm-grown clinical Pseudomonas aeruginosa isolates. Br J Biomed Sci 2007, 64:101-104.

68. Garo E, Eldridge GR, Goering MG, DeLancey PE, Hamilton MA, Costerton JW, James GA: Asiatic acid and corosolic acid enhance the susceptibility of Pseudomonas aeruginosa biofilms to tobramycin. Antimicrob Agents Chemother 2007, 51:1813-1817.

69. Eckert R, Brady KM, Greenberg EP, Qi F, Yarbrough DK, He J, McHardy I, Anderson $\mathrm{MH}$, Shi W: Enhancement of antimicrobial activity against Pseudomonas aeruginosa by coadministration of $\mathrm{G} 10 \mathrm{KHC}$ and tobramycin. Antimicrob Agents Chemother 2006, 50:3833-3838.

70. Landry RM, An D, Hupp JT, Singh PK, Parsek MR: Mucin-Pseudomonas aeruginosa interactions promote biofilm formation and antibiotic resistance. Mol Microbiol 2006, 59:142-151

71. Mikuniya T, Kato Y, Kariyama R, Monden K, Hikida M, Kumon H: Synergistic effect of fosfomycin and fluoroquinolones against Pseudomonas aeruginosa growing in a biofilm. Acta Med Okayama 2005, 59:209-216.

72. Norris P, Noble M, Francolini I, Vinogradov AM, Stewart PS, Ratner BD, Costerton JW, Stoodley P: Ultrasonically controlled release of ciprofloxacin from self-assembled coatings on poly(2-hydroxyethyl methacrylate) hydrogels for Pseudomonas aeruginosa biofilm prevention. Antimicrob Agents Chemother 2005, 49:4272-4279.

73. Hill D, Rose B, Pajkos A, Robinson M, Bye P, Bell S, Elkins M, Thompson B, Macleod C, Aaron SD, et al: Antibiotic susceptibilities of Pseudomonas aeruginosa isolates derived from patients with cystic fibrosis under aerobic, anaerobic, and biofilm conditions. J Clin Microbiol 2005 43:5085-5090.

74. Marques CN, Salisbury VC, Greenman J, Bowker KE, Nelson SM: Discrepancy between viable counts and light output as viability measurements, following ciprofloxacin challenge of self-bioluminescent Pseudomonas aeruginosa biofilms. J Antimicrob Chemother 2005, 56:665-671. 
75. Bjarnsholt $T$, Jensen $P \varnothing$, Burmølle $M$, Hentzer $M$, Haagensen JA, Hougen $H$ P, Calum H, Madsen KG, Moser C, Molin S, et al: Pseudomonas aeruginosa tolerance to tobramycin, hydrogen peroxide and polymorphonuclear leukocytes is quorum-sensing dependant. Microbiology 2005, 151:373-383.

76. Moskowitz SM, Foster JM, Emerson J, Burns JL: Clinically feasible biofilm suceptibility assay for isolates of Pseudomonas aeruginosa from patients with cystic fibrosis. J Clin Microbiol 2004, 42:1915-1922.

77. Brooun A, Liu S, Lewis K: A dose-response study of antibiotic resistance in Pseudomonas aeruginosa biofilms. Antimicrob Agents Chemother 2000, 44:640-646.

78. Goto T, Nakame $Y$, Nishida M, Ohi Y: In vitro bactericidal activities of betalactamases, amikacin, and fluoroquinolones against Pseudomonas aeruginosa biofilm in artificial urine. Urology 1999, 53:1058-1062.

79. Coquet $L$, Junter $G A$, Jouenne T: Resistance of artificial biofilms of Pseudomonas aeruginosa to imipenem and tobramycin. J Antimicrob Chemother 1998, 42:755-760.

80. Yassien M, Khadori N, Ahmedy A, Toama M: Modulation of biofilms of Pseudomonas aeruginosa by quinolones. Antimicrob Agents Chemother 1995, 39:2262-2268.

81. Soboh F, Khoury AE, Zamboni AC, Davidson D, Mittelman MW: Effects of ciprofloxacin and protamine sulfate combinations against catheterassociated Pseudomonas aerginosa biofilms. Antimicrob Agents Chemother 1995, 39:1281-1286.

82. Anwar H, Strap JL, Chen K, Costerton JW: Dynamic interactions of biofilms of mucoid Pseudomonas aeruginosa with tobramycin and piperacillin. Antimicrob Agents Chemother 1992, 36:1208-1214.

83. Brown MRW, Allison DG, Gilbert P: Resistance of bacterial biofilms to antibiotics a growth-rate related effect? J Antimicrob Chemother 1988, 22:777-780.

84. Evans DJ, Brown MRW, Allison DG, Gilbert P: Susceptibility of bacterial biofilms to tobramycin: Role of specific growth rate and phase in the division cycle. J Antimicrob Chemother 1990, 25:585-591.

85. Anderl JN, Zahller J, Roe F, Stewart PS: Role of nutrient limitation and stationary-phase existence in Klebsiella pneumoniae biofilm resistance to ampicillin and ciprofloxacin. Antimicrob Agents Chemother 2003, 47:1251-1256.

86. Worlitzsch D, Tarran R, Ulrich M, Schwab U, Cekici A, Meyer KC, Birrer P, Bellon G, Berger J, Weiss T, et al: Effects of reduced mucus oxygen concentration in airway Pseudomonas infections of cystic fibrosis patients. J Clin Investig 2002, 109:317-325.

87. Yoon SS, Hennigan RF, Hilliard GM, Ochsner UA, Parvatiyar K, Kamani MC, Allen HL, DeKievit TR, Gardner PR, Schwab U, et al: Pseudomonas aeruginosa anaerobic respiration in biofilms - relationships to cystic fibrosis pathogenesis. Dev Cell 2002, 3:593-603.

88. Yang L, Haagensen JA, Jelsbak L, Johansen HK, Sternberg C, Hoiby N, Molin S: In situ growth rates and biofilm development of Pseudomonas aeruginosa populations in chronic lung infections. J Bacteriol 2008, 190:2767-2776

89. Atlas RM: Handbook of microbiological media. Boca Raton: CRC Press; 1993.

90. Revsbech NP: An oxygen microsensor with a guard cathode. Limnol Oceanogr 1988, 34:474-478.

91. Rasmussen K, Lewandowski Z: Microelectrode measurements of local mass transport rates in heterogeneous biofilms. Biotechnol Bioeng 1998, 59:302-309.

92. Edgar R, Domrachev M, Lash AE: Gene expression omnibus: NCBI gene expression and hybridization array data repository. Nucleic Acids Res 2002, 30:207-210.

93. Benjamini $Y$, Hochberg $Y$ : Controlling the false discovery rate: a practical and powerful approach to multiple testing. J R Statist Soc B 1995 57:289-300.

94. Wong BCK, Chiu RWK, Tsui NBY, Chan KCA, CHan LW, Lau TK, Leung TN, Lo YMD: Circulating placental RNA in maternal plasma is associated with a preponderance of $5^{\prime}$ mRNA fragments: Implications for noninvasive prenatal diagnosis and monitoring. Clin Chem 2005, 51:1786-1795.

95. Pevsner J: Bioinformatics and functional genomics. Hoboken, NJ: John Wiley and Sons, 12003.

96. Huehn J, Siegmund K, Lehman JCU, Siewart C, Haubold U, Feuerer M, Debes GF, Lauber J, Frey O, Przybylski GK, et al: Developmental stage, phenotype, and migration distinguish naive- and effector/memory-like CD4+ regulatory T cells. J Exp Med 2004, 109:303-313.
97. Barrera L, Benner C, Tao Y-C, Winzler E, Zhou Y: Leveraging two-way probe-level block design for identifying differential gene expression with high-density oligonucleotide arrays. BMC Bioinformatics 2004, 5:42. 98. Conover WJ: Practical Nonparametric Statistics. John Wiley \& Sons, 31998.

doi:10.1186/1471-2180-10-294

Cite this article as: Folsom et al:: Physiology of Pseudomonas aeruginosa in biofilms as revealed by transcriptome analysis. BMC Microbiology 2010 10:294.

\section{Submit your next manuscript to BioMed Central and take full advantage of:}

- Convenient online submission

- Thorough peer review

- No space constraints or color figure charges

- Immediate publication on acceptance

- Inclusion in PubMed, CAS, Scopus and Google Scholar

- Research which is freely available for redistribution

Submit your manuscript at www.biomedcentral.com/submit
Ciomed Central 